\title{
PERAN ISLAM DALAM PERKEMBANGAN ILMU KEDOKTERAN
}

\author{
Rosydina Robi'aqolbi \\ Sekolah Tinggi Ilmu Al-Qur'an dan Sains Al-Ishlah (STIQSI) \\ Sendangagung Paciran Lamongan \\ Email: rosydina.rq@alishlah.ac.id
}

\begin{abstract}
Abstrak
Seiring dengan majunya perkembangan zaman belakangan ini, banyak masyarakat Indonesia yang beranggapan bahwa ilmu kedokteran berasal dari Barat. Oleh sebab itu, banyak yang meninggalkan karena mereka menganggap terapi berdasarkan ilmu kedokteran modern tidak dianjurkan dalam Islam. Selain itu, anggapan bahwa obat-obatan tersebut mengandung bahan kimia berbahaya. Padahal jika kita mau menelusuri dan menelaah lebih lanjut tentang peran Islam dalam perkembangan ilmu kedokteran, maka Islam memiliki kontribusi yang sangat besar, termasuk menjadi pelopor ilmu kedokteran, dan berkembang pesatnya ilmu tersebut pada masa kegemilangannya. Penelitian ini bermaksud mempelajari sejarah peran Islam dalam perkembangan ilmu kedokteran pada era kegemilangan Islam. Metode yang digunakan adalah pengumpulan sumber data, verifikasi sumber data, kemudian menginterpretasikan dan dilaporkan sebagai hasil penelitian. Hasil penelitian ini menunjukkan bahwa ilmu kedokteran dalam masa kegemilangan Islam berkembang begitu pesat. Hal tersebut terbukti dengan lahirnya tokoh-tokoh gemilang dalam dunia kedokteran dan karya-karya monumentalnya. Karya tersebut hingga saat ini masih banyak dibaca oleh para ilmuwan, serta metode terapinya yang sampai masih diterapkan hingga sekarang.
\end{abstract}

Kata Kunci: Islam, Kedokteran, Sejarah.

\section{A. PENDAhuluan}

\section{Latar Belakang}

Ilmu kedokteran di era modern saat ini masih terus berkembang begitu mengagumkan. Ilmu kedokteran juga tidak pernah lepas dari sejarah kegemilangan Islam di masa lampau. Sudah banyak sekali bukti adanya tokoh-tokoh kedokteran muslim yang pada masa kejayaan Islam menuliskan begitu banyak karya serta melahirkan metode pengobatan seperti pembedahan

Ilmu kedokteran yang saat ini masih terus berkembang dan maju pesat di barat dan seolah berkiblat pada dunia barat, menjadikan banyak umat Islam secara membabi buta menolak untuk menerima ajaran ilmu tersebut. Bahkan hingga tidak 
menerima karena menganggap bahwa pengobatan modern memberikan dampak yang tidak baik bagi Kesehatan. Ironisnya, hingga melupakan kontribusi ulamaulama muslim dalam sejarah perkembangannya.

Di sisi lain, tidak terbantahkan lagi bahwa Islam mengajarkan umatnya untuk mencintai ilmu pengetahuan. Terbukti bahwa wahyu Allah yang pertama kali turun melalui nabi Muhammad SAW adalah perintah untuk membaca, yaitu “iqra,", ayat pertama surat al-'Alaq. Sehingga pada penelitian ini, penulis akan membahas tentang sejarah perkembangan ilmu kedokteran modern dengan cara yang objektif dalam mencari sumber rujukan serta memverifikasinya.

Idealnya, sejarah harus merekam semua rentetan peristiwa yang telah terjadi kemudian diungkapkan segala sesuatunya berdasarkan fakta yang ada tanpa ada yang terpotong. Namun sayangnya, banyak catatan sejarah terpenggal sehingga rentetan peristiwa yang telah terjadi menjadi tidak utuh. Hal tersebut bisa dipengaruhi oleh kondisi sosial dan politik yang terjadi. Sehingga, dalam menuliskan sejarah perkembangan ilmu kedokteran serta peran Islam di dalamnya, perlu dilakukan upaya yang sebenar-benarnya dalam mengungkap fakta. Terlebih sejarah ilmu pengetahuan merupakan faktor yang sangat penting untuk kehidupan kita.

\section{Tujuan Penelitian}

Tujuan penelitian ini adalah untuk menambah wawasan khazanah sejarah ilmu kedokteran serta peran Islam dalam perkembangannya. Selain itu, penelitian ini juga mengungkap fakta-fakta sejarah serta faktor-faktor yang mendukung berkembangnya ilmu kedokteran yang terus maju hingga era sekarang ini. Penulis berharap tulisan ini dapat bermanfaat dalam menambah semangat keilmuan bagi generasi muda saat ini. Terkhusus bagi mahasiswa dan masyarakat umum yang lebih luas. Harapannya, kita bisa menjadi para pewaris ilmu pengetahuan dari para ulama terdahulu.

\section{B. METODE}

Hal yang paling penting dalam penelitian adalah merumuskan metodologi penelitian. Karena metodologi tersebut yang akan menjadi kerangka landasan dalam 
menjalankan kegiatan secara ilmia. ${ }^{1}$ Penulis dalam hal ini menggunakan metodologi sejarah, yaitu suatu proses menganalisis serta menguji secara kritis sebuah peninggalan atau rekam jejak peristiwa yang telah terjadi di masa lalu. ${ }^{2}$

Langkah-langkah dalam mengkaji menggunakan metode sejarah adalah sebagai berikut: ${ }^{3}$

1. Heuristik (pengumpulan sumber)

Heuristik adalah studi literatur yang merupakan sebuah keterampilan dalam menemukan dan memperinci bibliografi, mengumpulkan informasi tentang suatu subjek seperti bukti-bukti atau kesaksian-kesaksian. Dalam hal ini, penulis akan melakukan pencarian terhadap sumber-sumber tertulis yang terkait dengan sejarah perkembangan ilmu kedokteran.

2. Verifikasi (kritik sumber)

Tahapan verifikasi ini dilakukan untuk memperoleh sumber data yang valid atau shahih melalui kritik intern dan kritik ekstern. Kritik intern adalah upaya menentukan valid atau tidaknya sebuah bukti atau fakta sejarah yang ada. Yaitu dengan menentukan unsur tersebut adalah hal yang paling dekat dengan apa yang benar-benar terjadi, sejauh yang bisa diketahui berdasarkan referensireferensi terbaik yang ada. Sementara kritik ekstern merupakan upaya menyeleksi fisik dari sumber yang ditemukan. Misalnya jika sumber itu merupakan dokumen tertulis, maka yang harus dilihat adalah jenis kertas dan tintanya, gaya penulisannya, gaya bahasa dan kalimatnya, tata letaknya, serta penampilan luar lainnya.

Dalam hal ini, penulis memahami sebenar-benarnya sumber-sumber yang berkaitan dengan sejarah ilmu kedokteran serta peran Islam dalam perkembangannya dan membandingkannya dengan referensi yang lainnya.

3. Interpretasi (penafsiran)

Langkah yang dilakukan setelah verifikasi adalah menafsirkan sumbersumber data yang telah terseleksi dan terkumpul. Interpretasi seringkali disebut dengan analisis sejarah. Dalam hal ini, penulis akan menganalisis melalui

\footnotetext{
${ }^{1}$ Mardalis, Metodologi Penelitian, (Jakarta: Bumi Aksara, 2004), 25

${ }^{2}$ Louis Gottschalk, Mengerti Sejarah terjemahan Nugroho Notosusanto, (Jakarta: UI Press, 1985), 32

${ }^{3}$ Dudung Abdurrahman, Metodologi Penelitian Sejarah, (Yogyakarta: Ombak, 2011), 104.
} 
pendekatan antropologi sosial untuk menganalisis perubahan kondisi sosial yang terjadi dalam masa berkembangnya ilmu kedokteran.

4. Historiografi (penulisan sejarah)

Setelah semua tahapan dilalui, maka yang terakhir adalah menuliskan, memaparkan dan melaporkan hasil penelitian yang telah dilakukan. Seperti halnya laporan ilmiah lainnya, penulisan hasil penelitian sejarah seharusnya bisa memberikan gambaran yang terang tentang proses penelitian sejak awal, dimulai dari fase perencanaan sampai penarikan kesimpulan.

Dalam hal ini penulis akan mendeskripsikan data yang sudah dikumpulkan, diseleksi, diverifikasi dan diinterpretasi, kemudian penulisannya dibuat secara sistematis dan kronologis.

\section{A. PEMBAHASAN}

Agar pembahasan dalam tulisan ini menjadi lebih jelas dan tersusun secara sistematis, maka penyusunannya dibagi menjadi tiga bagian. Bagian pertama yaitu membahas tentang sejarah munculnya ilmu kedokteran pada masa sebelum Islam. Kedua, sejarah munculnya ilmu kedokteran dalam Islam. Ketiga, perkembangan ilmu kedokteran modern. Sebelum membahas lebih dalam tentang sejarah ilmu kedokteran, maka terlebih dahulu akan dijabarkan linimasa perkembangan ilmu kedokteran berdasarkan waktunya ${ }^{4}$ (Tabel 1).

Tabel 1. Linimasa Perkembangan Ilmu Kedokteran

\begin{tabular}{|c|l|}
\hline Tahun & \multicolumn{1}{|c|}{ Kejadian } \\
\hline $2600 \mathrm{SM}$ & $\begin{array}{l}\text { Imhotep di Mesir mendeskripsikan diagnosis dan terapi dari 200 } \\
\text { penyakit }\end{array}$ \\
\hline $500 \mathrm{SM}$ & Alcmaeon dari Croton membedakan antara vena dan arteri \\
\hline $460 \mathrm{SM}$ & $\begin{array}{l}\text { Hipokrates (Bapak Kedokteran) memulai studi ilmiah ilmu } \\
\text { kedokteran dan menemukan aspirin }\end{array}$ \\
\hline $300 \mathrm{SM}$ & Diocles menulis buku anatomi pertama kali \\
\hline $280 \mathrm{SM}$ & Herophilus mempelajari sistem saraf \\
\hline $60 \mathrm{M}$ & $\begin{array}{l}\text { Pedanius Dioscorides menulis De Materia Medica, buku tentang } \\
\text { bahan-bahan obat }\end{array}$ \\
\hline $130 \mathrm{M}$ & Lahirnya Galen, dokter yunani \\
\hline $910 \mathrm{M}$ & Rhazes (dokter Persia) mengidentifikasi smallpox (cacar) \\
\hline $1010 \mathrm{M}$ & Avicenna menulis buku The Canon of Medicine
\end{tabular}

${ }^{4}$ Rachel Hajar, M.D, History of Medicine Timeline, NCBI, Vol. 16, No. 1, 2015 


\begin{tabular}{|c|l|}
\hline $1249 \mathrm{M}$ & Roger Bacon menemukan kacamata \\
\hline $1489 \mathrm{M}$ & Leonardo da Vinci membedah mayat \\
\hline $1543 \mathrm{M}$ & $\begin{array}{l}\text { Vesalius mempublikasikan penemuan anatomi manusia dalam } \\
\text { bukunya De Fabrica Corporis Humani }\end{array}$ \\
\hline $1590 \mathrm{M}$ & Zacharius Jannssen menemukan mikroskop \\
\hline $1628 \mathrm{M}$ & $\begin{array}{l}\text { William Harvey mempublikasi studi anatomi gerakan jantung } \\
\text { dan pembuluh darah pada hewan yang menjadi dasar penelitian } \\
\text { tentang pembuluh darah dan jantung manusia }\end{array}$ \\
\hline $1656 \mathrm{M}$ & $\begin{array}{l}\text { Christopher Wren membuat percobaan transfuse darah pada } \\
\text { anjing }\end{array}$ \\
\hline $1670 \mathrm{M}$ & Anton van Leeuwenhoek menemukan sel darah merah \\
\hline $1683 \mathrm{M}$ & Anton van Leeuwenhoek meneliti tentang bakteri \\
\hline $1701 \mathrm{M}$ & Giacomo Pylarini memberi inokulasi cacar yang pertama \\
\hline $1747 \mathrm{M}$ & $\begin{array}{l}\text { James Lind mempublikasikan penelitiannya tentang kudis dan } \\
\text { menyatakan bahwa jeruk bisa mencegah kudis }\end{array}$ \\
\hline $1763 \mathrm{M}$ & Claudius Aymand sukses melakukan apendiktomi pertama kali \\
\hline $1796 \mathrm{M}$ & $\begin{array}{l}\text { Edward Jenner mengembangkan proses vaksinasi cacar air, } \\
\text { penemuan vaksin pertama kali }\end{array}$ \\
\hline
\end{tabular}

\begin{tabular}{|c|l|}
\hline Tahun & \multicolumn{1}{|c|}{ Kejadian } \\
\hline $1800 \mathrm{M}$ & $\begin{array}{l}\text { Humphry Davy menemukan bahan untuk anastesi dari nitrous } \\
\text { oxide }\end{array}$ \\
\hline $1816 \mathrm{M}$ & Rene Laennec menemukan stetoskop \\
\hline $1818 \mathrm{M}$ & $\begin{array}{l}\text { James Blundell sukses melakukan transfusi darah manusia } \\
\text { pertama kali }\end{array}$ \\
\hline $1842 \mathrm{M}$ & Crawford W. Long melakukan anastesi umum \\
\hline $1844 \mathrm{M}$ & Dr. Horace Well menggunakan nitrous oxide sebagai anastesi \\
\hline $1849 \mathrm{M}$ & $\begin{array}{l}\text { William Morton melakukan proses anastesi pertama kali dalam } \\
\text { praktik kedokteran gigi }\end{array}$ \\
\hline $1849 \mathrm{M}$ & $\begin{array}{l}\text { Elizabeth Blackwell perempuan pertama yang mempelajari ilmu } \\
\text { kedokteran formal di Geneva Medical College di New York }\end{array}$ \\
\hline $1853 \mathrm{M}$ & $\begin{array}{l}\text { Charles Gabriel Pravaz dan Alexander Wood mengembangkan } \\
\text { jarum suntik }\end{array}$ \\
\hline $1857 \mathrm{M}$ & $\begin{array}{l}\text { Louis Pasteur mengidentifikasi bahwa kuman adalah penyebab } \\
\text { penyakit }\end{array}$ \\
\hline $1867 \mathrm{M}$ & $\begin{array}{l}\text { Joseph Lister mengembangkan penggunakan antiseptik sebelum } \\
\text { metode bedah }\end{array}$ \\
\hline $1870 \mathrm{M}$ & $\begin{array}{l}\text { Robert Koch dan Louis Pasteur mengembangkan teori tentang } \\
\text { kiman coharai nanvahah nanvakit }\end{array}$ \\
\hline
\end{tabular}




\begin{tabular}{|l|l|} 
& \\
\hline $1879 \mathrm{M}$ & Vaksin pertama dikembangkan untuk kolera \\
\hline $1881 \mathrm{M}$ & Vaksin pertama dikembangkan untuk antrax oleh Louis Pasteur \\
\hline $1882 \mathrm{M}$ & $\begin{array}{l}\text { Vaksin pertama kali dikembangkan untuk rabies oleh Louis } \\
\text { Pasteur }\end{array}$ \\
\hline & Robert Koch menemukan basilus tuberculosis \\
\hline $1887 \mathrm{M}$ & Pertama kali kontak lensa ditemukan \\
\hline $1890 \mathrm{M}$ & $\begin{array}{l}\text { Emil von Behring menemukan anti racun dan mengembangkan } \\
\text { vaksin tetanus dan difteri }\end{array}$ \\
\hline $1895 \mathrm{M}$ & Wilhelm Conrad Roentgen menemukan x-ray \\
\hline $1896 \mathrm{M}$ & Vaksin pertama ditemukan untuk tifoid \\
\hline $1897 \mathrm{M}$ & Vaksin pertama ditemukan untuk bercak bubonic \\
\hline $1897 \mathrm{M}$ & Felix Hoffman mengembangkan aspirin \\
\hline $1901 \mathrm{M}$ & $\begin{array}{l}\text { Karl Landsteiner mengemukakan sistem golongan darah A, B, } \\
\text { AB, dan O }\end{array}$ \\
\hline $1921 \mathrm{M}$ & $\begin{array}{l}\text { Edward Mellanby menemukan penyakit akibat kekurangan } \\
\text { vitamin D }\end{array}$ \\
\hline $1922 \mathrm{M}$ & Insulin pertama kali digunakan sebagai terapi diabetes \\
\hline $1923 \mathrm{M}$ & Vaksin difteri pertama kali digunakan \\
\hline $1926 \mathrm{M}$ & Vaksin pertussis pertama kali digunakan \\
\hline $1927 \mathrm{M}$ & Vaksin tuberculosis dan tetanus pertama kali digunakan \\
\hline $1928 \mathrm{M}$ & Alexander Fleming menemukan penicillin \\
\hline & \\
\hline
\end{tabular}

\begin{tabular}{|c|l|}
\hline Tahun & \multicolumn{1}{|c|}{ Kejadian } \\
\hline \multirow{2}{*}{$1935 \mathrm{M}$} & Vaksin pertama kali untuk demam kuning \\
\cline { 2 - 3 } & $\begin{array}{l}\text { Percy Lavon Julian menggunakan terapi physostigmine untuk } \\
\text { glaucoma dan kortison sebagai terapi rheumatoid artritis }\end{array}$ \\
\hline \multirow{2}{*}{$1937 \mathrm{M}$} & Vaksin pertama digunakan untuk tifoid \\
\cline { 2 - 3 } & Bernard Fantus mempelopori penggunaan bank darah di Chicago \\
\hline $1942 \mathrm{M}$ & Docotr Karl Theodore Dussik mempublikasi ultrasound \\
\hline $1943 \mathrm{M}$ & Selman A Waksman menemukan antibiotic streptomisin \\
\hline $1945 \mathrm{M}$ & Vaksin influenza pertama kali digunakan \\
\hline $1950 \mathrm{M}$ & John Hopps menemukan alat pacu jantung pertama kali \\
\hline \multirow{2}{*}{$1952 \mathrm{M}$} & Paul Zoll mengembangkan alat pacu jantung \\
\cline { 2 - 3 } & Jonas Salk mengembangkan vaksin polio pertama kali \\
\cline { 2 - 3 } & $\begin{array}{l}\text { Rosalind Franklind menggunakan x-ray untuk mempelajari } \\
\text { struktur DNA }\end{array}$ \\
\hline \multirow{2}{*}{$1953 \mathrm{M}$} & $\begin{array}{l}\text { James Watson dan Francis Crick mempelajari struktur molekul } \\
\text { DNA }\end{array}$ \\
\hline & Gertrude Elion mematenkan terapi untuk melawan leukemia \\
\cline { 2 - 2 } &
\end{tabular}




\begin{tabular}{|l|l|}
\hline $1954 \mathrm{M}$ & $\begin{array}{l}\text { Dr. joseph E Murray melaksanakan transplantasi ginjal pertama } \\
\text { kali }\end{array}$ \\
\hline $1963 \mathrm{M}$ & Thomas Fogarty menemukan balon kateter embolektomi \\
\hline $1964 \mathrm{M}$ & Vaksin campak pertama kali \\
\hline \multirow{2}{*}{$1967 \mathrm{M}$} & Vaksin mumps pertama kali \\
\cline { 2 - 3 } & Dr. Chistian benard melakukan transplantasi jantung pertama kali \\
\hline $1970 \mathrm{M}$ & Vaksin pertama kali untuk rubella \\
\hline $1974 \mathrm{M}$ & Vaksin pertama kali untuk cacar air \\
\hline $1975 \mathrm{M}$ & Robert S. Ledley menemukan CAT scans \\
\hline $1977 \mathrm{M}$ & Vaksin pertama untuk pneumonia \\
\hline \multirow{2}{*}{$1978 \mathrm{M}$} & Bayi tabung pertama kali dilahirkan \\
\cline { 2 - 3 } & Vaksin pertama kali untuk meningitis \\
\hline $1980 \mathrm{M}$ & Eradikasi smallpox (cacar) \\
\hline $1981 \mathrm{M}$ & Vaksin pertama kali untuk hepatitis B \\
\hline $1983 \mathrm{M}$ & Identifikasi virus HIV penyebab AIDS \\
\hline $1984 \mathrm{M}$ & Alec Jeffreys merancang metode sidik jari genetic \\
\hline $1985 \mathrm{M}$ & Willem J. Kolff menemukan mesin dialysis \\
\hline $1992 \mathrm{M}$ & Vaksin pertama kali untuk hepatitis A \\
\hline $1996 \mathrm{M}$ & Dolly kambing hasil cloning pertama kali \\
\hline $2006 \mathrm{M}$ & Vaksin pertama untuk kanker \\
\hline & \\
\hline
\end{tabular}

Penulis menggunakan pendekatan antropologi sosial yang merupakan sebuah studi tentang kehidupan sehari-hari dalam sebuah komunitas di masa lalu.

Lembaga-lembaga politik, agama, pendidikan, ekonomi, dan lembaga lainnya merupakan beberapa potongan teka-teki yang membentuk sebuah peradaban. Melalui beberapa potongan teka-teki tersebut, penulis akan menguraikan sebuah sejarah ilmu kedokteran serta peran Islam dalam perkembangannya.

\section{Sejarah munculnya ilmu kedokteran}

\section{a. Masa Prasejarah}

Meskipun belum diketahui sejak kapan pastinya tumbuhan dijadikan sebagai obat-obatan sebagaimana manusia kuno menggunakan tanah maupun tanah liat sebagai terapi, namun pada tahun 7000 sebelum masehi ditemukan bukti arkeologi kedokteran 
gigi menggunakan bor dan tali busur yang berujung batu. ${ }^{5}$ Berdasarkan analisis arkeologi juga ditemukan bahwa amputasi sudah pernah dilakukan pada 4900 tahun sebelum masehi di Perancis. $^{6}$

\section{b. Masa Peradaban Awal}

\section{Mesopotamia}

Catatan awal pengobatan berasal dari periode Babilonia, sebuah kota tua di Mesopotamia (sekarang Irak) pada tahun 2112 - 2004 sebelum Masehi. Pengobatan berupa resep medis yang ditulis oleh dokter ketika ada seseorang yang sakit. ${ }^{7}$ Namun pengobatan pada masa Mesopotamia kuno sulit dibedakan antara pengobatan berdasarkan akal (sains rasional) ataukah sihir. ${ }^{8}$ Meskipun begitu, didapatkan buku rujukan diagnosis yang berisi daftar gejala serta pengamatan empiris dan logis secara terperinci, kemungkinan pemulihan, penyebab serta perkembangannya. Buku tersebut ditulis oleh cendikiawan dari Borsippa selama masa pemerintahan raja Adad di Babilonia (1069 - 1046 SM). ${ }^{9}$ Pada saat itu, pasien dirawat dengan cara perawatan yang sampai saat ini masih digunakan seperti perban, herbal dan krim. ${ }^{10}$

Dalam budaya Semit Timur, pengobatan utama disebut asipu, sejenis pengobatan untuk mengusir setan. ${ }^{11}$ Orang yang bisa memberikan pengobatan seperti itu biasanya diturunkan dan

\footnotetext{
${ }^{5}$ Anonym, Stone age man used dentist drill, 2006.

http://news.bbc.co.uk/2/hi/science/nature/4882968.stm diakses pada tanggal 21 April 2020

${ }^{6}$ Buquet M., Philippe C., Anaick S, A Possible Early Neolithic Amputation at Butheirs-Boulancourt (Seine-et-Marne), Freance, Antiquity: A Review of World Archaeology, Vol 83, Issue 322, 2009

${ }^{7}$ R.D. Biggs, Medicine, Surgery, and Public Health in Ancient Mesopotamia, Journal of Assyrian Academic Studies, Vol. 19, No. 1, 2005, 7-18

${ }^{8}$ Walter Farber, Witchcraft, Magic, and Divination in Ancient Mesopotamia, Civilizations of the Ancient Near East. 3. (New York: Charles Schribner's Sons, MacMillan Library Reference, Simon \& Schuster MacMillan, 1995), 1891-908.

${ }^{9}$ Heeßel, N. P, Diagnosis, Divination, and Disease: Towards an Understanding of the Rationale Behind the Babylonian Diagonostic Handbook, (In Horstmanshoff, H.F., 2004); Stol Marten; Tilburg, Cornelis (eds.). Magic and Rationality in Ancient Near Eastern and Graeco-Roman Medicine. Studies in Ancient Medicine.

${ }^{10}$ Horstmanshoff, H.F.J.; Tilburg, CR Van; Stol, M, Magic and Rationality in Ancient Near Eastern and Graeco-Roman Medicine, (Leiden: Brill, 2004).

${ }^{11}$ Abusch, Tzvi, Mesopotamian Witchcraft: Towards a History and Understanding of Babylonian Witchcraft Beliefs and Literature, (Leiden, The Netherlands: Brill, 2002), 56.
} 
dijunjung tinggi. Pada masa itu, sudah dikenal juga penyakit yang berkaitan dengan gangguan mental. Namun penyakit mental diyakini sebagai penyakit yang disebabkan oleh dewa tertentu, jika mereka berhalusinasi melihat anjing maka diperkirakan akan meninggal, sementara jika berhalusinasi melihat rusa, maka ia akan sembuh. Disfungsi ereksi dinyatakan sebagai gangguan psikologis. $^{12}$

\section{Mesir}

Imhotep adalah dokter pertama Mesir kuno dan dianggap sebagai penulis asli Edwin Smith Papyrus pada masa 3000 SM. ${ }^{13}$ Imhotep merupakan kepala menteri Raja Djoser yang merancang salah satu piramida paling awal di Saqqarah, kemudian Imhotep dianggap sebagai dewa pengobatan Mesir yang identic dengan dewa Yunani, Asclepius. Di dalam Edwin Smith Papyrus, terdapat catatan yang sangat rinci terkait pemeriksaan, diagnosis, perawatan dan prognosis berbagai macam penyakit, yang sepenuhnya tanpa pemikiran magis. ${ }^{14}$ Institusi medis yang disebut Rumah Kehidupan, telah didirikan di Mesir kuno pada tahun 2200 SM. ${ }^{15}$

\section{India}

Atharvaveda merupakan sebuah buku suci agama Hindu sejak awal zaman besi, atharvaveda merumuskan tentang pengobatan dan berbagai resep herbal untuk menuju Ayurveda yang bermakna pengetahuan lengkap untuk berumur panjang. Sintesis praktik herbal serta konseptualisasi teori secara besar-besaran terjadi pada tahun 600 SM, pada saat Ayurveda dipelajari pada institusi Charaka dan Sushruta. ${ }^{16}$ Charaka merupakan seorang dokter dan Sushruta merupakan seorang ahli bedah.

\footnotetext{
${ }^{12}$ Nemet-Nejat, Karen Rhea, Daily Life in Ancient Mesopotamia, Daily Life. Santa Barbara, (California: Greenwood, 1998), 80.

${ }^{13}$ J.H. Breasted, The Edwin Smith Surgical Papyrus, (University of Chicago Press, 1930).

${ }^{14}$ Edwin Smith papyrus, Britannica Online Encyclopedia, Britannica.com, diakses pada tanggal 22 April 2020

${ }^{15}$ Museum: House of Life, www.ucl.ac.uk, diakses pada tanggal 22 April 2020

${ }^{16}$ The Kahun Gynaecological Papyrus, Reshafim.org.il
} 
Menurut ringkasan Charaka, kesehatan merupakan upaya manusia. Sushruta mendefinisikan tujuan pengobatan untuk menyembuhkan orang sakit, melindungi yang sehat, dan memperpanjang usia. Sushruta Samhita dikenal mampu menggambarkan prosedur pembedahan seperti operasi katarak, operasi hidung, telinga, dan beberapa eksisi lainnya. Dia memiliki klasifikasi diagnosis terdiri dari 184 bab, termasuk cedera dan penyakit yang berkaitan dengan penuaan dan gangguan mental

Pada era ini penyakit smallpox (cacar) banyak terjadi, dan praktik inokulasi mulai banyak dilakukan. ${ }^{17}$ Masa emas kedokteran di India terjadi pada tahun $800 \mathrm{SM}-1000 \mathrm{M}$. Charaka mengetahui sekitar 500 macam tumbuhan obat, sementara Sushruta mengetahui sekitar 760 macam tumbuhan sebagai obat.

\section{China}

Sistem kedokteran di China tergolong independen dan tidak terpengaruh dengan faktor eksternal. Huangdi (kaisar kuning) menulis undang-undang kedokteran yang disebut Huangdi neijing. Dasar dari ilmu tradisional cina adalah dualistik kosmik teori "yinyang". Sehingga dasar pengobatannya lebih berdasarkan pada kosmologi daripada biologi, ${ }^{18}$ misalkan memiliki prinsip seperti pria, aktif dan ringan, diibaratkan sebagai surga. Sementara Yin, memiliki prinsip seperti perempuan, pasif dan gelap, diibaratkan seperti bumi. Tubuh manusia seperti benda lain pada umumnya, terdiri dari lima unsur, yaitu kayu, api, tanah, logam, dan air. Tujuan pengobatan Tiongkok kuno adalah mengendalikan proporsi mereka dalam tubuh. ${ }^{19}$

Ilmu kedokteran China tradisional didasarkan pada pengobatan herbal dan akupuntur serta beberapa terapi pijat, metode pengobatan tersebut terjadi selama ribuan tahun. Hingga diperkenalkan metode pengobatan barat pada era dinasti Qing abad ke 18, meskipun para dokter di China

\footnotetext{
${ }^{17}$ Robert G., History of Medicine, https://www.britannica.com/science/history-of-medicine diakses pada tanggal 22 April 2020.

${ }^{18}$ Furth, Charlotte, A Flourishing Yin: Gender in China's Medical History, 960-1665. (Berkeley: University of California Press, 1999), 19

${ }^{19}$ Frank Dikotter, "China" in Roy Porter, ed, The Cambridge History of Science: 18th-century Science, Vol 4, 2003, 695-97
} 
masih belum menerima. ${ }^{19}$ Akhirnya pada abad ke-19, pengobatan barat diperkenalkan di tingkat lokal oleh misionaris medis dari London ${ }^{20}$.Kebiasaan sosial di China bahwa pria dan wanita tidak seharusnya berdekatan satu sama lain, maka para wanita China tidak ingin dirawat oleh dokter pria China. Para misionaris mengirim dokter wanita seperti dr. Mary Hannah Fulton (1854-1927 M) didukung oleh dewan misi gereja Presbyterian (AS) pada tahun 1902 M mendirikan perguruan medis pertama untuk wanita di Cina, yaitu perguruan tinggi Hackett di Guangzhou. $^{21}$

\section{Yunani dan Kekaisaran Romawi}

Asklepios, seperti halnya Imhotep, dia dianggap sebagai dewa penyembuhan. Di Yunani terdapat kuil-kuil yang didedikasikan untuk Asklepios disebut sebagai Asklepieia. Kuil tersebut berfungsi sebagai tempat untuk saran terapi, menentukan prognosis dan pusat terapi. ${ }^{22}$ Kuil dianggap sebagai tempat suci, dimana di dalamnya pasien akan memasuki kondisi tidur dengan induksi mimipi yang disebut sebagai enkoimesis. Mereka yang sembuh dianggap menerima petunjuk dari dewa dalam mimpi. $^{23}$

Dalam asclepeion Epidaurus, terdapat tiga papan marmer besar yang tertanggal $350 \mathrm{SM}$, mencatat sejarah 70 kasus, keluhan serta penyembuhan. Beberapa terapi seperti pembedahan abses di perut atau proses mengeluarkan benda asing juga tercatat. Mereka melakukan prosedur pembedahan dalam kondisi pasien tidur (enkoimesis) dengan bantuan opioid. Almaecon dari Corton menulis tentang sistem saraf optik pada tahun 500-450 SM. ${ }^{24}$ Kemudian pada tahun 460-370 SM, Hipocrates

\footnotetext{
${ }^{20}$ TJ Hinrichs; Linda L Barnes; et al., Chinese Medicine and Healing: An Illustrated History, (Harvard University Press, 2012), 197

${ }^{21}$ Edward T. James; et al., eds. Notable American Women, 1607-1950: A Biographical Dictionary. (Harvard U.P., 1971), Vol 2, 685-86

${ }^{22}$ Risse, G.B., Mending bodies, saving souls: a history of hospitals, (London: Oxford University Press, 1990), 56

${ }^{23}$ Askitopoulou, H.; Konsolaki, E.; Ramoutsaki, I.; Anastassaki, E., Surgical cures by sleep induction as the Asclepieion of Epidaurus, The history of anesthesia: proceedings of the Fifth International Symposium, by José Carlos Diz, Avelino Franco, Douglas R. Bacon, J. Rupreht, Julián Alvarez. Elsevier Science B.V., International Congress Series 1242, 2002, 11-17

${ }^{24}$ Almaecon, Stanford Encyclopedia of Philosophy, https://plato.stanford.edu/entries/alcmaeon/ diakses pada tanggal 22 April 2020.
} 
lahir sebagai bapak kedokteran. ${ }^{25}$ Yang paling dikenal dalam sejarah adalah sumpah Hipokrates bagi para dokter yang berisi aspek-aspek etika menjadi dokter.

Hipokrates dan para muridnya telah banyak menjabarkan berbagai macam penyakit serta kondisi medisnya. Hipokrates diberikan penghargaan karena mampu mendeskripsikan jari tabuh sebagai tanda pada penyakit paru supuratif kronis, kanker paru dan penyakit jantung. ${ }^{26}$ Hipokrates adalah orang pertama yang mengkategorikan penyakit sebagai akut, kronis, endemik, epidemi, serta menggunakan istilah-istilah seperti eksaserbasi, kambuh, serangan mendadak, puncak, dan pemulihan. ${ }^{27}$ Kontribusi lain Hipokrates yaitu menguraikan tentang gejala penyakit, temuan fisik, perawatan dan prognosis pada empiema toraks (terdapatnya nanah pada lapisan selaput rongga dada). Sampai saat ini, cara pembedahan dan pengobatannya masih relevan digunakan. Selain itu, Hipokrates juga berperan dalam bidan ilmu kedokteran yang terintegrasi dan holistik, termasuk pentingnya anamnesis pasien dan menanyakan riwayat makan dan paparan lingkungan sebagai faktor yang berpengaruh terhadap penyakitnya. ${ }^{28}$

Setelah Hipokrates, lahirlah seorang dokter terhebat pada masa Yunani kuno bernama Galen (129-216 M), dia belajar ilmu kedokteran secara luas di Roma. Dia membedah binatang untuk mempelajari anatomi tubuh. Dia berani melakukan tindakan bedah mayor seperti operasi kepala, yang setelahnya selama hampir dua ribu tahun sudah tidak pernah dikerjakan lagi. Dia juga menulis buku yang berjudul Ars Medica (Seni Kedokteran). ${ }^{29}$ Sampai abad pertengahan, ilmu anatomi dan model fisiologi Galen masih menjadi rujukan, namun sempat berhenti akibat beberapa hasil pemikiran Galen salah, karena saat itu, membedah mayat

\footnotetext{
${ }^{25}$ The Father of Modern Medicine: Hippocrates, 2008, Archived from the original on 2008-02-28.

${ }^{26}$ Finger Clubbing, Cancer Research UK, https://www.cancerresearchuk.org/aboutcancer/mesothelioma/symptoms/finger-clubbing diakses pada tanggal 20 April 2020

${ }^{27}$ Irvine Loudon, Western Medicine: An Illustrated History, (London: Oxford University Press, 2003).

${ }^{28}$ Francis Adams, The Genuine Works of Hippocrates, (New York: William Wood and Company, 1891).

${ }^{29}$ Rudolph E. Siegel, Galen's system of physiology and medicine (Karger, 1973)
} 
adalah hal yang tabu dan tidak dibenarkan. ${ }^{30}$ Tetapi kemudian pada abad pertengahan pembedahan mayat mulai dilakukan. ${ }^{31}$

Pada tahun $1523 \mathrm{M}$, Galen menerbitkan buku tentang anatomi tubuh manusia yang berjudul On the Natural Faculties di London. Kemudian Andreas Vesalius, seorang dokter ahli anatomi dari Belgia meluncurkan proyek penerjemahan besar-besaran buku tersebut ke dalam bahasa Latin pada tahun $1530 \mathrm{M}$. Karya Vesalius yang paling terkenal adalah De Humani Corporis Fabrica, dalam karya tersebut terdapat pengaruh besar dari tulisan Galen. ${ }^{32}$ Sementara bangsa Romawi membuat banyak instrumen pembedahan, seperti forsep, pisau bedah, kauter, gunting silang, dan jarum bedah. ${ }^{33}$ Seorang dokter tentara Romawi Dioscorides (40-90 M) yang merupakan ahli farmakologi dan botani menulis ensiklopedia De Materia Medica yang menggambarkan lebih dari 600 obat herbal, digunakan secara luas selama 1500 tahun. ${ }^{34}$ Sebelumnya, orang-orang kristen di awal kekaisaran Romawi memasukkan pengobatan ke dalam teologi, praktik ritual, dan metafora. ${ }^{35}$

\section{Sejarah Munculnya Ilmu Kedokteran dalam Islam}

Praktik pengobatan Bizantium berlangsung cukup lama selama abad pertengahan (400-1400 M) dan mempengaruhi lahirnya pengobatan Islam serta lahirnya ilmu kedokteran zaman Renaisans. Para dokter Bizantium membuat standarisasi pengetahuan medis ke dalam buku catatan, catatan mereka cukup lengkap mencakup diagnosis dan teknis pengobatan. Kompendium Medis dalam tujuh buku yang ditulis oleh dokter Paul dan Aegina sebagai ringkasan pengobatan medis bertahan menjadi rujukan selama 800 tahun setelahnya.

Setelah jatuhnya Roma pada abad ke-5, dunia barat kehilangan keingintahuan intelektual yang merupakan ciri dari zaman kuno klasik, dan

\footnotetext{
${ }^{30}$ Faith Wallis, Medieval Medicine: A Reader, Vol 14, No 26, 2010, 222

${ }^{31}$ Ronald Numbers, Galileo Goes to Jail and Other Myths About Science and Religion, (Harvard University Press, 2009), 45.

${ }^{32}$ Peter Dear, Revolutionizing the Sciences: European Knowledge and Its Ambitions, 1500- 1700, 2001, 37-39.

${ }^{33}$ Surgical Instruments from Ancient Rome, Healthsystem.virginia.edu

${ }^{34}$ Greek Medicine, US National Institutes of Health, 16 September 2002.

${ }^{35}$ Project MUSE, Journal of Late Antiquity, Vol 8, No 2, 2015
} 
tidak menemukan hasrat intelektualnya sampai munculnya Renaissance Eropa berabad-abad kemudian. Di saat Eropa melalui masa kegelapannya, Persia mengalami masa-masa kegemilangannya dalam dunia kedokteran dengan merujuk pada ajaran ilmuwan Yunani-Romawi serta menambahkan kontribusi baru dengan ilmu yang lebih logis.

Konstantinopel menjadi pusat pengobatan utama selama abad pertengahan, hal tersebut didukung oleh lokasi yang strategis, kesejahteraan negara dan keluasan wawasannya. Kasus kembar siam pertama kali yang berhasil dipisahkan pada abad ke-10 dan baru dilakukan kedua kalinya di Jerman pada abad ke-16. ${ }^{36}$ Di sebelah kekaisaran Bizantium, terdapat kekaisaran Sassaniyah Persia yang memiliki kontribusi penting dalam bidang kedokteran, yaitu pendirian akademi Gendeshapur yang menjadi pusat medis paling utama di masa lalu selama abad ke-6 dan ke-7. ${ }^{37}$

Peradaban Islam mulai meningkat menjadi rujukan dalam dunia kedokteran karena para dokternya memberikan kontribusi signifikan pada bidang kedokteran, termasuk anatomi, farmakologi, farmasi, fisiologi, oftalmologi, dan pembedahan. Mereka terpengaruh oleh praktik pengobatan dari India, Persia, Yunani, Romawi, dan Bizantium kuno. ${ }^{38}$ Zaman keemasan Islam dimulai dari abad ke 9-13 M, dimana pada masa tersebut berkembang budaya matematika, kedokteran dan sains di seluruh Persia. Dasar dari pengobatan Islam yang dikembangkan dari tradisi Yunani-Romawi, khususnya teori Hipokrates dan Galen, kemudian disintesis dan dikembangkan menjadi model pengobatan yang sangat logis, empiris, berbasis bukti dan eksperimental. ${ }^{39}$ Meskipun banyak dokter muslim, setidaknya terdapat lima orang yang sangat terkenal dalam kontribusinya kepada dunia kedokteran, yakni Al-Razi (865925 M), Al-Zahrawi (936-1013 M), Ibn Sina (980-1037 M), ibn Rushd (11261198 M), dan ibn Nafis (1213-1288 M). Pada Tabel 2 dipaparkan linimasa sejarah tokoh kedokteran.

\footnotetext{
${ }^{36}$ Denys Montandon, The Unspeakable History of Thoracopagus Twins' Separation, (Switzerland: ISAPS, 2015). Vol 9 (3).

${ }^{37}$ Cambridge History of Iran Volume 4, (Cambridge University Press, 1968), 396.

${ }^{38}$ Medieval Islamic Civilization: An Encyclopedia, by Josef W. Meri, Jere L. Bacharach, 783.

${ }^{39}$ Ebrahimnejad H, What is 'Islamic' in Islamic Medicine? An overview, Boston Studies in the Philosophy of Science, 2011, 275:259-70
} 


\begin{tabular}{|c|c|c|}
\hline \multicolumn{3}{|l|}{ Timeline } \\
\hline Hippocrates & 460-370 BCE & Greek physician; "Father of Modem Medicine" \\
\hline Aristotla & 384-322 BCE & Greek philosopher, scientist \\
\hline Galen & $129-\mathrm{Ca} 200 / 216 \mathrm{CE}$ & Greek physician, medical researcher \\
\hline Muhammad & $570-632 \mathrm{CE}$ & The Prophet \\
\hline Quran & $609 \mathrm{CE}$ & Islamic Holy Book \\
\hline Bimaristan & $707 \mathrm{CE} ; 88 \mathrm{H}$ & Hospital, first buit in Damascus \\
\hline Licensure & $931 \mathrm{CE} ; 318 \mathrm{H}$ & Licensure became mandatory \\
\hline al-Razi & 865-925 CE: $251-312 \mathrm{H}$ & Persian physician, philosopher, sciantist \\
\hline Abu-al-Casim & 936-1013 CE; 329-404 H & Arabic physician, most important surgeon in his era \\
\hline Ibn Sina & 980-1037 CE; 369-428 H & Persian polymath, physician \\
\hline Iton Zuhr & ca1094-1162 CE; 370-428 H & Arabic physician, experimental surgeon \\
\hline Ibn al-Baitar & 1197-1248 CE; 593-646 H & Arabic physician, pharmacist, scientist \\
\hline Ibn al-Nafis & $1213-1288 \mathrm{CE} ; 609-678 \mathrm{H}$ & Arabic physician, physiologist \\
\hline Mansur Ibn llyas & $1380-1422 \mathrm{CE} ; 782-824 \mathrm{H}$ & Persian physician, illustrated atlas of anatomy \\
\hline
\end{tabular}

Tabel 2. Linimasa sejarah tokoh kedokteran ${ }^{40}$

Sebanyak 129 karya Galen diterjemahkan ke dalam bahasa Arab oleh Christian Nestorian Hunayn ibn Ishaq. Selain itu, pendekatan sistematis yang rasional serta penetapan pola pengobatan Islam akhirnya dengan cepat ilmu kedokteran menyebar ke seluruh kekaisaran Arab. ${ }^{41}$ Para tokoh terkemuka yang memiliki keahlian dalam banyak bidang, Muhammad ibn Zakariya al-Razi dan Avicenna dari Persia, menulis lebih dari 40 karya di bidang kesehatan, kedokteran dan kesejahteraan. Mereka merujuk pada ilmuwan Yunani dan Roma, menjaga ilmu kedokteran tetap bergerak maju. ${ }^{42}$

Rumah sakit pertama kali yang didirikan oleh umat Islam adalah Bimaristan. Rumah sakit tersebut sekaligus menjadi pusat pendidikan kedokteran. Sejarah mencatat bahwa Bimaristan awal berdiri menggunakan tenda sederhana atas perintah Nabi Muhammad SAW untuk para prajurit korban perang Khandaq. Rumah sakit tersebut didirikan pada masa dinasti Umayyah oleh khalifah Al Walid bin Abdul Malik pada tahun 707 M di Damaskus. $^{43}$

\footnotetext{
${ }^{40}$ Hawa Edriss, et al., Islamic Medicine In The Middle Age, American Journal f Medicine Science, Vol 345, No 3, 2017, 223-229.

${ }^{41}$ George Sarton, Introduction to the History of Science, (cf. Dr. A. Zahoor and Dr. Z. Haq, 1997), Quotations From Famous Historians of Science, Cyberistan.

${ }^{42}$ Kill or cure An Illustrated History of Medicine (cf. Steve Parker, 2013)

${ }^{43}$ Nagamia HF, "Islamic medicine history and current practice”. Dalam Journal Intelectual, Social, Historical of Islamic Medicine, Vol. 2, No 4, 2003, 19-30
} 
Ar-Razi, yang memiliki nama lengkap Muhammad ibn Zakariya alRazi, lahir di Iran (865-925 M) merupakan tokoh pertama yang mempertanyakan teori kedokteran Yunani tentang sistem humoral, dan teori tersebut hingga saat ini masih digunakan. ${ }^{44}$ Beliau menguasai beberapa bidang ilmu, diantaranya kedokteran, filsafat, musik, matematika, fisika, farmasi dan kimia. Beberapa karya Ar-Razi yaitu "on Surgery" dan "A General Book on Therapy", beliau juga orang yang pertama mengenali reflex pupil terhadap cahaya. ${ }^{45}$

Al-Razi diutus memimpin Rumah Sakit Royal oleh al-Mansour pada tahun 903 M. Selama waktu itu, dia menulis dua buku, al-Mansouri fi al Tibb (Buku tentang obat), buku tersebut ia dedikasikan untuk al-Mansur, menggambarkan berbagai penyakit medis sekaligus terapinya dan menjadi sumber rujukan utama kurikulum kedokteran di Universitas Barat. Buku tersebut diterjemahkan dalam bahasa Latin pada tahun 1187 dengan judul Liber ad Almansoris dan menjadi buku medis terbanyak dibaca di Eropa selama masa kegelapan. ${ }^{46}$ Buku kedua yaitu Al-Tibb al-Ruhani (The Spiritual Physic), tentang pengobatan spiritual dan psikologis. Buku-buku beliau lebih dari 200 manuskrip dan diperkirakan lebih dari 1000 telah diterjemahkan ke dalam bahasa Latin, Inggris, Prancis, Italia, Ibrani, dan Jerman.

Al-Razi juga berkontribusi besar dalam bidang penelitian. Beliau melakukan uji klinis pertama kali (kontrol kasus). Buku Al-Razi yang paling terkenal adalah kitab al-Hawi fi al-tibb (buku komprehensif tentang kedokteran, dikenal juga sebagai The Virtous Life). Selain itu bukunya yang berjudul al-Jadari wa al-Hasbah (campak dan cacar) juga menjadi rujukan ilmuwan Eropa dan menjadi cikal bakal berkembangnya inokulasi dan vaksin.

\footnotetext{
${ }^{44}$ Pormann, Peter E., Smith, E. Savage, Medieval Islamic medicine, (Washington DC: Georgetown University, 2007), 43-45. On the dominance of the Greek humoral theory, which was the basis for the practice of bloodletting, in medieval Islamic medicine.

${ }^{45}$ Elgood, Cyril, A Medical History of Persia and The Eastern Caliphate (1st ed.), (London: Cambridge, 2010), 202-203

${ }^{46}$ Al-Razi- the Clinician. Islamic culture and the medical arts. U.S. National Library of Medicine. Available at: https://www.nlm.nih.gov/exhibition/islam ic_medical/islamic_06.html
} 


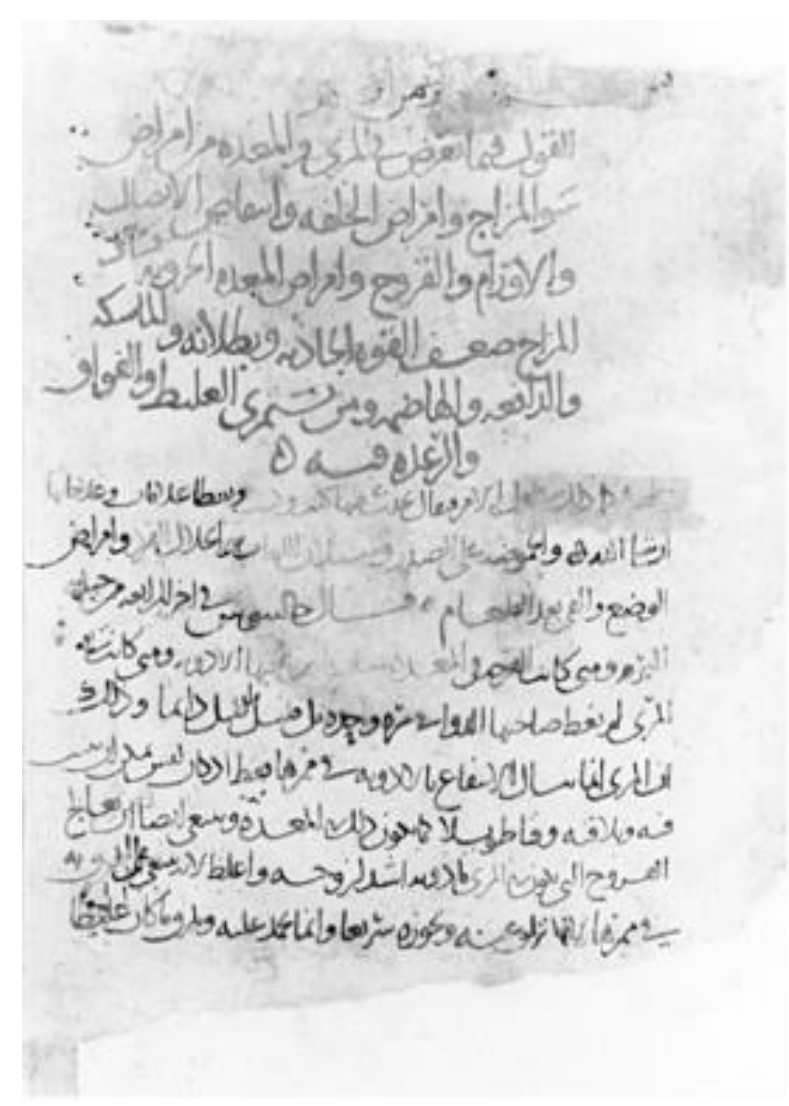

Gambar 1. Potongan buku Al-Hawi fi a-tibb karya al-Razi (925 M/ 312 H) yang ada di National Library of Medicine, Bethesda. ${ }^{47}$

Dalam bukunya al-Hawi, al-Razi mengkritisi filsuf Yunani, Aristoteles dan Plato serta mengembangkan ide-ide inovatif pada banyak mata pelajaran. Dia juga mengkritisi Galen tentang teori demam karena banyak kasus yang ia temui tidak sesuai dengan deskripsi demam oleh Galen. Dia juga mengkritisi Galen tentang cara membedakan satu penyakit dengan penyakit lainnya bahwa bukan dengan kencing tetapi menggunakan sistem humoral dalam bukunya Al-Shukuk Ala Jalinus (Keraguan pada Galen). ${ }^{48}$

Avicenna (Ibn Sina) yang memiliki nama asli Abu Ali al-Husayn ibn Abdullah ibn Al-hasan ibn Ali ibn Sina, dilahirkan di kota kecil yang sekarang menjadi bagian dari Afganistan. Ibn Sina menguasai beberapa ilmu selain ilmu kedokteran, yaitu psikologi, farmakologi, geologi, fisika, astronomi dan kimia. Beliau disebut sebagai bapak kedokteran, menulis

\footnotetext{
${ }^{47}$ https://www.nlm.nih.gov/exhibition/ islamic_medical/Islamic_06

${ }^{48}$ Mohaghegh M., The "Kitab al-Shukuk'alas JItlinus" of Muhammad ibn Zachariya al-Razi. Dalam Medicine in Islamic Culture, Vol. 2, No. 3, 1988, 207-12
} 
buku yang berjudul "The Canon of Medicine", sebuah ikhtisar pengetahuan medis kontemporer dari dunia Islam yang dipengaruhi oleh tradisi sebelumnya termasuk pengobatan Yunani-Romawi (khususnya Galen), digunakan menjadi rujukan di berbagai universitas Eropa pada abad pertengahan. $^{49}$

Selain buku al-Qanun fi al-Tibb (The Canon of Medicine), buku yang paling terkenal yang lain adalah kitab ash-Shifa (kitab Penyembuhan). Dan yang terakhir ada buku ensiklopedia medis yang luas terdiri dari lebih dari satu juta kata, dibagi menjadi banyak bagian. Dalam buku tersebut, ibn Sina memadukan pengamatan sendiri dan teori Galen serta filsafat Aristoteles. ${ }^{50}$

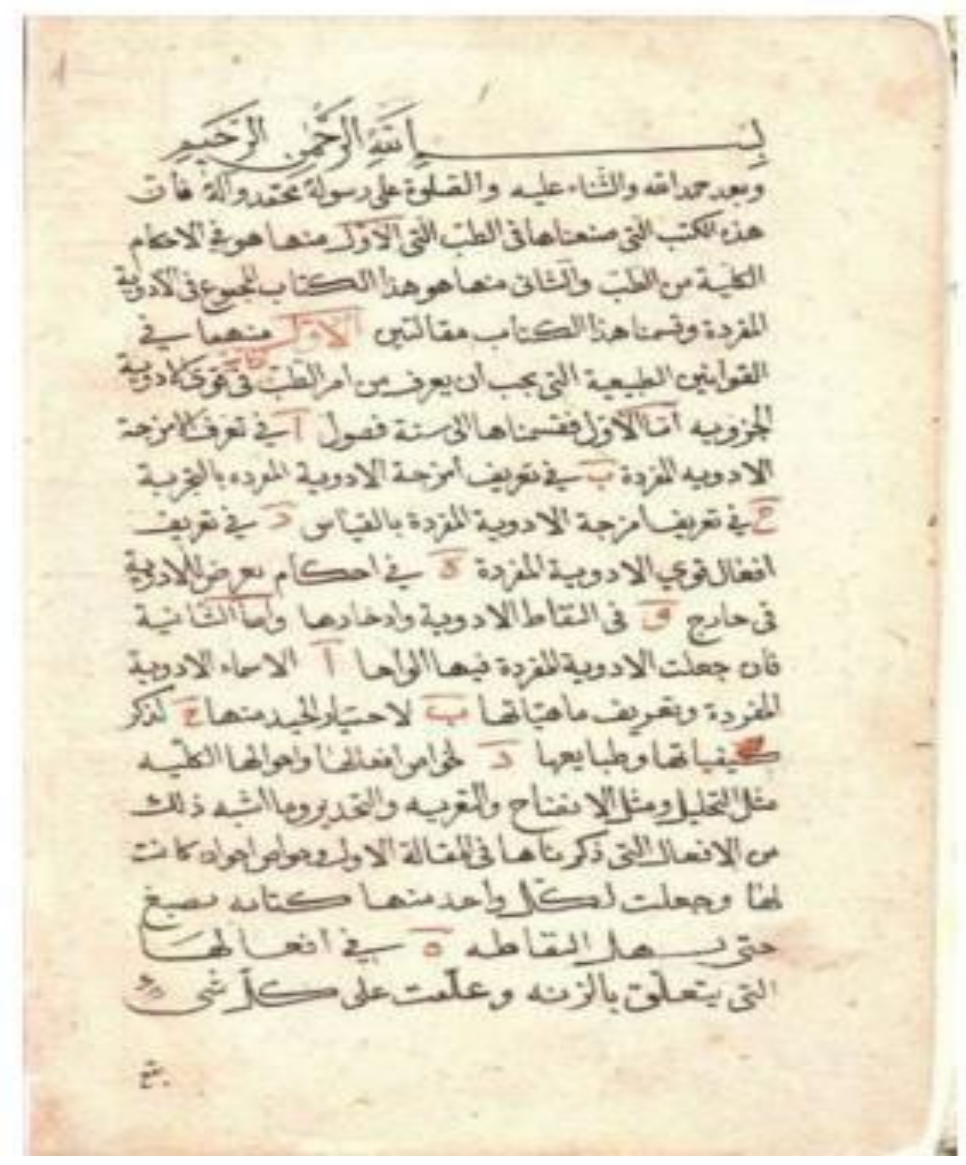

Gambar 2. Potongan buku al-Qonun fi al-Tibb ${ }^{51}$

Buku al-Qonun fi al-Tibb diterjemahkan ke berbagai bahasa, dicetak 40 kali di Eropa pada abad ke 15 sampai 18. Publikasi ilmiah tentang ibn Sina

\footnotetext{
49 Avicenna, The Canon of Medicine, (Encyclopædia Britannica, 2008).

${ }^{50}$ Nasser M, Tibi A, Savage-Smith E., "Ibn Sina's Canon of Medicine: 11th century rules for assessing the effect of drugs". Dalam Journal Reseach Social Medicine, 102, 2009, 78-80

${ }^{51}$ https://en.wikipedia.org/ wiki/Avicenna/media/File:IbnSinaCanon1.jpg.
} 
mencapai 750 baik artikel maupun buku dari tahun 1906 M sampai 2006 M. Abu Abas Al-Nabati, seorang ahli botani, memasukkan metode ilmiah dalam farmakologi dan menerbitkan beberapa karya dengan rincian klasifikasi biologis dan penggunaanya. Apoteker yang paling berpengaruh pada abad ke 12 adalah murid beliau, yaitu Abu Muhammad Abdullah Ibnu Ahmad Ibn Al-Baitar. ${ }^{52}$

Ibn Al-Baitar menulis kitab al-Jami' limufradat al-adwiya wa alaghdhiya (ringkasan tentang obat dan makanan sederhana), sebuah ensiklopedia farmasi yang mencatat sekitar 1.400 tanaman, makanan dan mineral, serta ensiklopedia utama untuk perawatan kondisi medis tertentu dalam kitab al-mughni fi al-adwiya al-mufrada. Abu al-Qasim Khalaf ibn alAbbas az-Zahrawi (936-1013 M) menemukan berbagai instrumen bedah, termasuk benang catgut, ligator, jarum bedah, retraktor. Dia melakukan trakeostomi dan litotomi. ${ }^{53}$ Ibn Zuhr (Avenzoar, 1094-1162 M), adalah ahli bedah yang melakukan eksperimen pertama kali, dia menguji hewan untuk melakukan pembedahan otopsi postmortem kemudian dia lakukan kepada manusia. Dia menjelaskan tentang penyakit perikarditis, mediastinitis dan kelumpuhan (paralisis) faring. Ibn al-Nafis (1213-1288 M) menjelaskan dasar fisiologi peredaran darah dan merupakan orang pertama yang menggambarkan sirkulasi paru-paru dan sirkulasi jantung koroner. ${ }^{54}$ Mansur ibn Muhammad ibn Ahmad ibn Yusuf Ibnu Ilyas (1380-1422 M) adalah seorang dokter yang menulis buku ilustrasi warna untuk anatomi tubuh manusia. $^{55}$

\footnotetext{
${ }^{52}$ Savage-Smith E, A brochure to accompany an exhibition in celebration of the 900th anniversary of the oldest Arabic medical, manuscript in the collections of the National Library of Medicine

${ }^{53}$ Falagas ME, Zarkadoulia EA, Samonis G., Arab science in the golden age (750-1258 C.E.). FASEB J 2006, 20, 1581-6

${ }^{54}$ Aloud A. Ibn al-Nafis and the discovery of the pulmonary circulation. Dalam Southwest Respiratory and Critical Care Chronicles, 2017

${ }^{55}$ Islamic culture and the medical arts. Anatomy. U.S. National Library of Medicine
} 

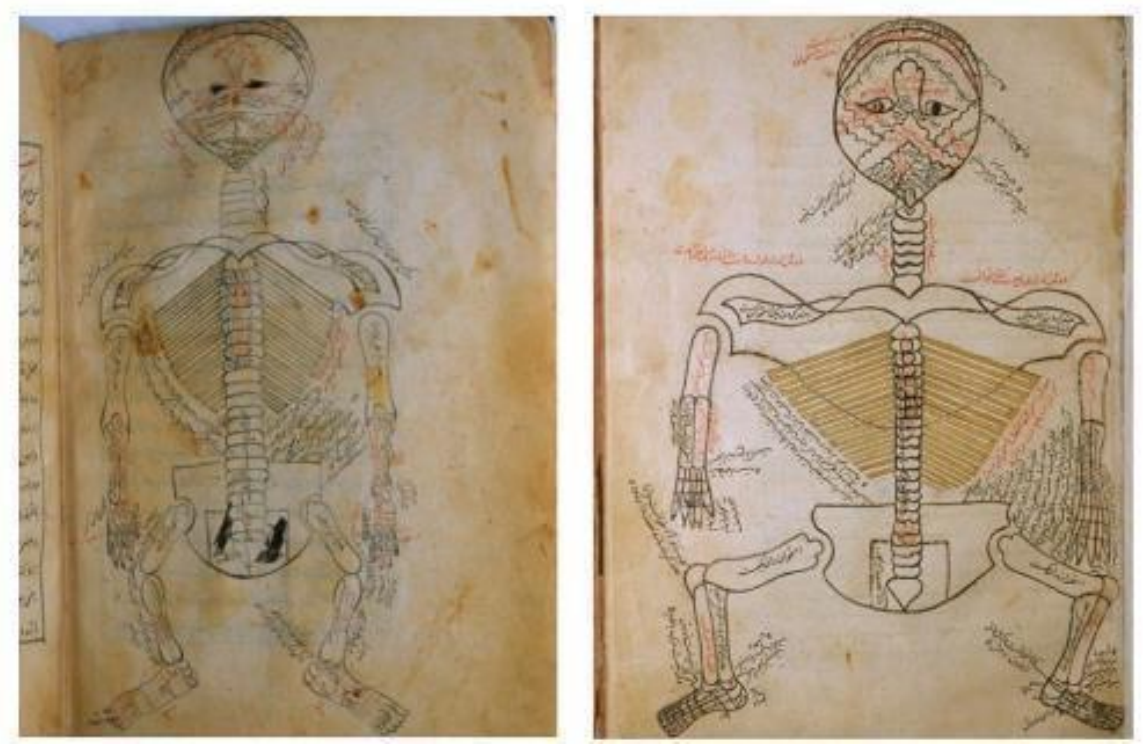

Gambar 3. Potongan buku Manshur's Anatomy

\section{Perkembangan Ilmu Kedokteran Modern}

Renaisans, merupakan masa transisi atau peralihan antara abad pertengahan menuju modern, yakni abad ke-14 sampai abad ke-17. Pada masa ini banyak peralihan budaya, banyak terjadi kemajuan intelektual, sehingga disebut sebagai masa lahirnya kembali bagi bangsa Eropa. Banyak dijumpai upaya besar-besaran untuk menerjemahkan karya-karya ilmiyah bahasa Arab dan Yunani ke dalam bahasa Latin. Meskipun begitu, para sejarawan lebih banyak menyoroti kesinambungan antara masa Renaisans dengan abad pertengahan, dan banyak yang terputus dengan masa awal sejarah. ${ }^{56}$

\section{KESIMPULAN}

Dalam sejarah perkembangan ilmu kedokteran yang terus berkembang hingga saat ini, tidak luput peran dan kontribusi besar dari umat Islam pada masa kejayaannya berabad-abad tahun pada masa pertengahan. Karya-karya yang dilahirkan oleh para ilmuwan muslim bahkan hingga saat ini masih relevan menjadi sumber dasar rujukan bagi perkembangan ilmu kedokteran. Ilmu kedokteran yang berkembang sebelum Islam lebih mengarah pada ilmu magis, kosmotis dibandingkan ilmu biologis. Sementara Islam membawa pembaharuan

${ }^{56}$ Monfasani, John .2016.. Renaissance Humanism, from the Middle Ages to Modern Times. 
pada ilmu kedokteran menjadi lebih logis dan empiris berdasarkan bukti dan analisis serta penelitian eksperimental. Hal tersebut menjadi bukti bahwa Islam sangat menghargai dan mencintai ilmu pengetahuan, dalam hal ini ilmu kedokteran.

\section{DAFTAR PUSTAKA}

A., Aloud Ibn al-Nafis and the discovery of the pulmonary circulation, Southwest Respiratory and Critical Care Chronicles 2, 2017.

Abdurrahman, Dudung, Metodologi Penelitian Sejarah, Yogyakarta: Ombak, 2011.

Abusch, Tzvi, Mesopotamian Witchcraft: Towards a History and Understanding of Babylonian Witchcraft Beliefs and Literature, Leiden, The Netherlands: Brill, 2002.

Adams, Francis, The Genuine Works of Hippocrates, New York: William Wood and Company, 1891.

Al-Qur'an Al-Karim.

Almaecon, Stanford Encyclopedia of Philosophy. Diakses pada tanggal 22 April 2020, https://plato.stanford.edu/entries/alcmaeon/.

Anonym, Stone age man used dentist drill, 2006. Diakses pada tanggal 21 April 2020, http://news.bbc.co.uk/2/hi/science/nature/4882968.stm.

Askitopoulou, H., et al., Surgical cures by sleep induction as the Asclepieion of Epidaurus, The history of anesthesia: proceedings of the ${ }^{5 t h}$ international Symposium, by José Carlos Diz, et al. International Congress Series 1242, 2002, 11-17.

Biggs, R.D., "Medicine, Surgery, and Public Health in Ancient Mesopotamia", Journal of Assyrian Academic Studies, Vol. 19, No. 1 (2005), 7-18.

Buquet M., Philippe C., Anaick S., A Possible Early Neolithic Amputation at ButheirsBoulancourt (Seine-et-Marne), Freance, Antiquity: A Review of World Archaeology, Vol. 83 Issue 322, 2009. 
Breasted, J.H., The Edwin Smith Surgical Papyrus, (University of Chicago Press, 1930). Britannica.com. diakses pada tanggal 22 April 2020 "Edwin Smith papyrus = Britannica Online Encyclopedia".

Cambridge History of Iran Vol. 4, Cambridge University Press, 1968, 396.

Cancer Research UK, Finger Clubbing, Diakses pada tanggal 20 April 2020, https://www.cancerresearchuk.org/aboutcancer/mesothelioma/symptoms/fi $\underline{\text { n ger-clubbing. }}$

Dear, Peter, "Revolutionizing the Sciences: European Knowledge and Its Ambitions, 1500-1700," (2001), 37-39.

Dikotter, Frank, China in Roy Porter, "The Cambridge History of Science," Vol 4 (2003), 695-97.

Ebrahimnejad, Hormoz, What is 'Islamic' in Islamic Medicine? An overview, Boston Studies in the Philosophy of Science, (2011), 275:259-70.

Edriss, Hawa, et al., "Islamic Medicine in The Middle Age," American Journal of Medicine Science, Vol. 345, No. 3 (2017), 223-229.

Elgood, Cyril, A Medical History of Persia and The Eastern Caliphate (1st ed.), London: Cambridge, 2010.

Encyclopædia Britannica, The Canon of Medicine (work by Avicenna), 2008.

Falagas ME, Zarkadoulia EA, Samonis G, Arab science in the golden age (750-1258 C.E.). FASEB J, 2006, 20:1581-6.

Farber, Walter, Witchcraft, Magic, and Divination in Ancient Mesopotamia. Civilizations of the Ancient Near East, New York: Charles Schribner's Sons, MacMillan Library Reference, Simon \& Schuster MacMillan, 1995

Furth, Charlotte, A Flourishing Yin: Gender in China's Medical History, 960-

1665, Berkeley: University of California Press, 1999.

Healthsystem.virginia.edu, Surgical Instruments from Ancient Rome.

Heeßel, N. P., Diagnosis, Divination, and Disease: Towards an Understanding of the Rationale Behind the Babylonian Diagonostic Handbook, 2004.

Hippocrates, The Father of Modern Medicine, 2008. Diakses pada tanggal 22 April 2020.

Horstmanshoff, H.F.J.; Tilburg, CR Van; Stol, M, Magic and Rationality in Ancient Near Eastern and Graeco-Roman Medicine, Leiden: Brill, 2004.

Https://en.wikipedia.org/ wiki/Avicenna/media/File:IbnSinaCanon1.jpg. 
Https://www.nlm.nih.gov/exhibition/Islamic_medical/Islamic_06

James, Edward T., et al., Notable American Women, 1607-1950: A Biographical Dictionary, Harvard U.P, Vol 2, 1971, 685-86.

Loudon, Irvine, Western Medicine: An Illustrated History, Londok: Oxford University Press, 2002.

Montandon, Denys, The Unspeakable History of Thoracopagus Twins' Separation, Switzerland: ISAPS 2015, Vol 9 (3).

Meri, Josef W., Jere L., Medieval Islamic Civilization: An Encyclopedia, by. Bacharach, 783.

Sarton, George, Introduction to the History of Science, Dr. A. Zahoor and Dr. Z. Haq. Quotations from Famous Historians of Science, Cyberistan, 1997.

Wallis, Faith, Medieval Medicine: A Reader, 2010.

Monfasani, John, Renaissance Humanism, from the Middle Ages to Modern Times, 2016.

Gottschalk, Louis, Mengerti Sejarah terjemahan Nugroho Notosusanto, Jakarta: UI Press, 1985.

Hinrichs, TJ., Linda L Barnes et al., Chinese Medicine and Healing: An Illustrated History, Harvard University Press, 2012.

M Nasser, Tibi A, Savage-Smith E., Ibn Sina's Canon of Medicine: 11th century rules for assessing the effect of drugs, Journal Research Social Medicine (2009), $102,78-80$.

Mardalis, Metodologi Penelitian, Jakarta: Bumi Aksara, 2004.

Mohaghegh M. Ali, The "Kitab al-Shukuk'alas JItlinus" of Muhammad ibn Zachariya al-Razi, Medicine in Islamic Culture, MJIRI, Vol. 2, No. 3 (1988), 207-12.

HF., Nagamia, "Islamic medicine history and current practice." J Intl Soc Hist Islamic Med, Vol. 2, No. 4 (2003), 19-30.

Nemet-Nejat, Karen Rhea, Daily Life in Ancient Mesopotamia, Daily Life, Santa Barbara, California: Greenwood, 1998.

Numbers, Ronald, Galileo Goes to Jail and Other Myths About Science and Religion, Harvard University Press, 2009.

Parker, Steve, Kill or cure An Illustrated History of Medicine, 2013. 
Pormann, Peter E., Smith, E. Savage, Medieval Islamic medicine, (Washington DC: Georgetown University (2007), 10, 43-45.

Project MUSE, Journal of Late Antiquity, Vol. 8, No. 2, 2015", muse.jhu.edu.

Hajar, Rachel, "History of Medicine Timeline." NCBI, Vol. 16, No. 1 (2015),

Reshafim.org.il., The Kahun Gynaecological Papyrus.

Risse, G.B., Mending bodies, saving souls: a history of hospitals, Oxford University Press, 1990.

Richardson, Robert G., History of Medicine, diakses pada tanggal 22 April 2020, https://www.britannica.com/science/history-of-medicine.

Savage-Smith E. A brochure to accompany an exhibition in celebration of the 900th anniversary of the oldest Arabic medical manuscript in the collections of the National Library of Medicine. National Library of Medicine.

Siegel, Rudolph E., Galen's system of physiology and medicine, 1973.

Syaifulloh, M. Khafid, "Faktor Kepercayaan Masyarakat terhadap Pengobatan Medis dan Alternatif," Jurnal Fakultas Kedokteran Universitas Sebelas Maret, 2016.

U.S. National Library of Medicine, Islamic culture and the medical arts.Anatomy.

US National Institutes of Health, Greek Medicine, 2002.

www.ucl.ac.uk, Museum: House of Life, diakses pada tanggal 22 April 2020. 